\title{
Social Competence and Career Development: Validation of a Scale with Secondary Students*
}

\author{
Competencia social y desarrollo profesional: validación \\ de una escala de estudiantes secundarios
}

Enviado: 17 de junio de 2013 | Revisado: 23 de abril de 2015 | Aceptado: 23 de abril de 2015

\author{
JoAna CARneiro Pinto** \\ Catholic University, Portugal \\ MARIA do CÉU TAVEIRA **** \\ University of Minho, Portugal \\ LILIANA FARIA ***** \\ Institución ISLA Campus Lisboa - Laureate International \\ Universities, Portugal \\ ADELINDA CANDEIAS ****** \\ Institución University of Évora, Portugal
}

doi:10.11144/Javeriana.upsy14-3.sccd

Para citar este artículo: Carneiro, J., Taveira, M. C., Faria, L., \& Candeias, A. (2015). Social competence and career development: validation of a scale with secondary students Universitas Psychologica, 14(3), 889-898. http://dx.doi.org/10.11144/Javeriana.upsy14-3.sccd

\section{* Research article}

** Joana Carneiro Pinto, is a professor of the 1st cycle of studies in Psychology, at the Faculty of Human Sciences, Portuguese Catholic University. She holds a Ph.D. in Psychology with a specialization in Vocational Psychology (2010), and a degree in Psychology, from the School of Psychology, University of Minho (2007). Her thesis is untitled "Self-career management: study of a psychological intervention model with research grant-holders", concerning a theme that is in the transition between vocational psychology and social and organizational psychology. Currently she teaches general psychology, psychology of learning, educational psychology, psychometrics, psychological assessment, statistics applied to psychology, quantitative methods, and development of academic and professional skills seminar. Researcher in projects related to health, well-being and life projects, needs assessment and effectiveness of psychological interventions, and scientific research methodologies. Correo electrónico: joanacpinto_@hotmail.com

**** Correo electrónico: ceuta@psi.uminho.pt

****** Correo electrónico: lilianafaria@delphis.com.pt

${ }^{* * * * * * *}$ Correo electrónico: adelindacandeias@gmail.com

\section{A B S T R A C T}

This paper presents a validation study of the Perceived Social Competence in Career Scale (SCCarS). The sample included 571 adolescents, 283 girls (49.6\%) and 287 boys $(50.3 \%)$, aged 14 to 25 years old $(\mu=16.33 \pm 1.41)$, $10^{\text {th }}$ and $11^{\text {th }}$ grade students attending secondary schools in the northern, central and southern Portugal. Exploratory factor analysis indicates the presence of eight factors, with eigenvalues superior to 1.00 , explaining $79.16 \%$ of the total variance of the items. Confirmatory factor analysis provided support to the factorial structure of eight factors, with adequate fit indices $\left(X^{2}\right)$ $\mathrm{df}=4.229, \mathrm{CFI}=0.909, \mathrm{GFI}=0.869, \mathrm{RMSEA}=0.079, \mathrm{p}=0.000)$. These results are consistent with the factorial structure found in previous studies carried out with Portuguese samples from $8^{\text {th }}$ grade. Implications are drawn related to the need for further study of the psychometric characteristics of the SCCarS with young people from different age groups.

Keywords

social competence; career development; adolescents; confirmatory factor analysis

\section{RESUMEN}

Este trabajo presenta un estudio de validación de la Escala de Competencia Social Percibida en la Carrera (ECSCar). La muestra incluyó 571 adolescentes, 283 mujeres (49.6\%) y 287 hombres (50.3\%), de 14 a 25 años de edad $(\mu=16.33 \pm 1.41)$, estudiantes de $10^{\circ}$ y $11^{\circ}$ grado de escuelas secundarias en el norte, centro y sur de Portugal. El análisis factorial exploratorio indica la presencia de ocho factores con valores propios superiores a 1.00, que explican $79.16 \%$ de la varianza total de los ítems. El análisis factorial confirmatorio apoya la estructura factorial de ocho factores con los índices de ajuste adecuados $\left(X^{2} / \mathrm{df}=4.229, \mathrm{CFI}=0.909, \mathrm{GFI}=0.869, \mathrm{RMSEA}=\right.$ $0.079, \mathrm{p}=0.000$ ). Estos resultados son consistentes con la estructura factorial encontrada en estudios previos realizados con muestras de portugueses de $8^{\circ}$ grado. Se elaboran implicaciones relativas a la necesidad de un mayor estudio de las características psicométricas de la ECSCar con jóvenes de diferentes grupos de edad.

Palabras clave

competencia social; desarrollo profesional; adolescentes; análisis factorial confirmatorio 
Over the past two decades, the need for more holistic and systemic psychological models has caused social competence to be viewed as a complex and dynamic concept. However, the difficulties in its definition, and consequently, its valid measurement and utility, continue to difficult the practical impact of the literature on social competence.

In a literature review conducted In 2011, Humphrey and colleagues conducted a literature review found that there is an overlap between the social competence concept and a whole range of other concepts, such as social skills, social awareness, social literacy, social intelligence, emotional skills, affective skills, and interpersonal skills (Humphrey et al., 2011). Some authors have been arguing that the difficulty in defining this concept is due to the wide range of skills, knowledge and attitudes that are associated with it, such as the ability to apologize, to be empathic, to make and keep friends, to express feelings and ideas positively, and to solve problems (Waters \& Sroufe, 1983). Currently, it is increasingly assumed that the concept of social competence is multidimensional and interactive, having a broad meaning. Social competence includes social, emotional and cognitive dimensions. It enables a person to engage in specific situations of interaction that are socially accepted as healthy and effective, through the selection and implementation of a set of personal (e.g., metacognition, learning, motivation, thought and knowledge) and environmental resources (e.g., informational resources and materials available) to obtain personally relevant goals (Candeias \& Almeida, 2005).

As regards the assessment instruments, authors are unanimous in considering that a valid assessment of this construct should include multiple methods, informants, and indicators (Lemos \& Meneses, 2002). In terms of assessment methods, it may be used questionnaires, scales, naturalistic or experimental observations, interviews, and roleplays. As for the informants, besides the assessment that the person makes about the degree to which he/she has a set of abilities that enable him/her to have a competent performance in social and interpersonal situations (self-assessment instruments), often it is also considered the perception of significant others, such as parents, teachers, and peers (hetero assessment). And, considering the indicators, it is common to refer to personal characteristics, self-esteem, and self-efficacy beliefs, among others, as variables that help to conceptualize and operationalize social competencies. Thus, currently, there are available several assessment tools. As an example, in a systematic review on the main instruments used in the assessment of social and emotional competence, a total of 12 were recorded, 4 of which assess only social competence (e.g., Social Competence and Behavior Evaluation Scale), and other 4 assess simultaneously social and emotional competences (e.g., Bar-On Emotional Quotient Inventory). This clearly demonstrates that there isn't an agreement on how to measure this concept (Humphrey et al., 2011).

Regarding its usefulness, several studies have associated, with clinical and/or statistical significance, the concept of social competence with motivation, adaptability, performance and achievement, successful experiences, and well-being in different life domains such as the academic, professional/occupational, and social (Carvalho, 2011; Cecconello, 1999; Humphrey et al., 2011; Lemos $\&$ Menzes, 2002). In today's society it is important that people know how to manage their careers, that is, they should have the ability to explore their interests, abilities and values, as well as the world in which they live; to develop clear and realistic career goals, taking into account the individual and societal needs; to design and implement action plans that increase the probability of obtaining those goals, considering the current labor market conditions; and, to constantly assess the impact of their actions and decisions, in themselves and others (e.g., Greenhaus, Callanan \& Godschalk, 2010; Pinto, 2010). For this reason, some authors argue that social skills are the foundation of career skills (e.g., Railiene \& Gudzinskiene, 2012). However, despite the growing interest in this concept, there is a lack of study of its usefulness in the field of career development.

With the concern to operationalize this conceptualization of social competence as the ability to select and implement the most appropriate resourc- 
es to deal with the challenges of an interpersonal situation, with a behavioral and situational nature, the PSCS - Perceived Social Competence Scale was developed. The preliminary studies of conceptualization and operationalization of the construct have been ongoing throughout the last decade, with several normative groups (e.g., children and adolescents from 6 to 18 years, nursing professionals), taking the self-assessments of competence in everyday specific social and interpersonal situations (Candeias, 2001; Candeias \& Almeida, 2005). This study will focus on the work with PSCS- Car - Perceived Social Competence Scale in Career - after its adaptation to career development situations, in order to proceed to its validation, with a sample of 571 adolescents, students from the 10th and 11th grades attending secondary schools, in the northern, central and southern Portugal.

\section{Method}

\section{Participants}

Participants were 571 adolescents from both sexes, (283, 49.6\% girls and 287, 50.3\% boys), aged 14 to 25 years old $(\mu=16.33 \pm 1.41)$. These adolescents were $10^{\text {th }}$ grade $(\mathrm{n}=296 ; 149$ girls and 146 boys; $\mu=15.76 \pm 1.1$ years old) and $11^{\text {th }}$ grade $(\mathrm{n}=275$; 134 girls and 141 boys; $\mu=16.95 \pm 1.45$ years old) students attending secondary schools, in the northern (Viana do Castelo=2), central (Lisboa=1) and southern (Évora=1) Portugal.

\section{Instrument}

The Perceived Social Competence in Career Scale (PSCS-Car; Araújo, Taveira, \& Candeias, 2009) is a self-report instrument designed to assess the social competence of adolescents in career development situations. This scale is derived from the adaptation of a prior instrument - The Perceived Social Competence Scale (PSCS; Carvalho, 2001) - to career situations. The social situations presented are hypothetical, and are aimed at evaluating the ability of young people to use a variety of behavioral and cognitive skills to handle interpersonal situations. These situations involve significant pairs and adults, with a more formal or informal character, within the career.

Table 1 shows the example situation and the six social situations adapted to the career context: (a) homework situation, (b) double date situation, (c) lead a group situation, (d) friend counselor situation, (e) parents meeting situation, and (f) student visitor situation. Each social situation is presented with four questions: (a) this would be difficult for me, (b) this would be easy for me, (c) my performance in this situation would be poor, and (d) my performance in this situation would be excellent, which stimulate the reflection on the level of performance (poor/excellent), as well as, on the level of ease/difficulty perceived in the task. For each question, participants must respond according to a five points Likert scale, where 1 represents "never" and 5 represents "always". The items related to the self-assessment of difficulty and poor performance on the task need to be reversed.

In its original version, the PSCS has a structure of six factors corresponding to the six social situations in an academic context, explaining 64\% of the total variance of the instrument, with high factor loadings ranging between .46 and .85 (Candeias, 2008; Candeias \& Almeida, 2005). The rates of internal consistency are adequate, with Cronbach's alphas greater than .75 on all subscales.

\section{Procedures}

This study is part of a larger research project designated "Career and citizenship: personal and contextual conditions for ethical questioning of life-career projects" "This project aims, among other goals, helping to fill a gap regarding the contribution of the social skills to an ethical questioning of life projects. To this end, the main goals of this study were presented to the school boards of several educational institutions in northern, central and

1 Project funded by the Study "Career and citizenship development: Personal and contextual conditions for ethical questioning of life-career projects" financed by FCT - Fundação para a Ciência e Tecnologia, and Programa Compete (PTDC/CPECED/098896/2008). 
TABLE 1.

Perceived Social Competence in Career Scale

\begin{abstract}
Example situation
There will be a contest of work presentations in your school. This class is preparing an issue to expose orally on the day of the contest. Each class must choose a spokesperson to present and defend the work publicly.

1. Homework situation - items 1.1 to 1.4

The school psychologist defined weekly meetings with the students to lead vocational guidance and development activities. In these meetings, students have thought about themselves, about what they know and need to know about the academic and professional world, and also about what they will need in order to make decisions about their future as students and workers. The task this week is individual and involves carrying out a description of themselves, where students should highlight what they love, what they do best, what they value most, and what are their future goals. The students demonstrate doubts about this task and ask the psychologist to be heard. The psychologist agreed to talk to a representative of the students on the subject and the questions raised.
\end{abstract}

2. Double date situation - items 2.1 a 2.4

The brother of your best friend is a less good phase, because it has no desire to attend classes, study and behave properly with teachers and peers. He has shown difficulty in judging the usefulness of the school and school diplomas. As you are a good friend, your friend asks your help to try to liven up his/her brother, and help him/her understand why school is important for the future, whether as individuals or as employees. So, your friend asks you to accompany him to a meeting with his brother, stipulating that at a certain time he/she retires, and leaves you alone with his/her brother to chat.

3. Lead a group situation - items 3.1 a 3.4

The school board decided to create a weekly hour in which students must participate in a club. They have to choose from several alternatives, such as sports, music, journalism, mathematics, English, fine arts, experiences in the natural and physical-chemical sciences, or even help in the community clubs. Each class director asked to be chosen a leader or a representative of the class to participate in the commission of the formation of clubs and help the colleagues to take a good decision and choose the most appropriate club for each. This student must be prepared to help colleagues to make the decision, and explain to the colleagues how to make good and bad decisions in school.

\title{
4. Friend counselor situation - items 4.1 a 4.4
}

Some friends are practically decided about attending college after the 12 th grade, but they are looking for a friend to help them plan the best way to succeed in their choice. This friend should be able to listen and give advice about what should be done to achieve good results in that decision.

5. Parents' meeting situation - items 5.1 a 5.4

The Portuguese teacher asked the students to prepare a work about the occupations of their parents. In this work, students should describe what they already know about these professions: it can be included interviews, photos or articles and images taken from the Internet. After the work done, at the end of the semester, it will be convened a parents' meeting, where students will have the opportunity to present to their teachers and parents, the result of their work. In order to better organize this event, the class decided to choose one representative from each group to make an introduction to the parents, of the work done by the respective group.

6. Student visitor situation - items 6.1 a 6.4

Students from this school are very excited about making a fair related to the world of work. Over the three days set aside for this fair, students can attend to presentations about occupations by various guest workers. Each class director asked his/her class to choose a class representative. This student must be a spokesman for the group, putting questions to professionals about their day-to-day work.

Source: own work

southern Portugal, as well as, to the students of the $10^{\text {th }}$ and $11^{\text {th }}$ grades, and their respective parents and teachers. After obtaining the informed consent by the parents, the PSCS- Car was administered to the students by a trained research assistant, during regular classes. The instructions needed to complete the instrument were indicated, and well as, the detailed ethical procedures associated with the study. The average time for completion of the scale was 20 minutes in each class.
Analysis

Data were processed with the IBM software SPSS and AMOS, version 19.0 for Windows. Firstly, descriptive statistics were run to the participants' characterization, as well as, the distribution of their responses to the items. An exploratory factor analysis, with varimax rotation was also carried out, considering the eigenvalues superior to 1.00 , the communalities superior to 0.70 , and factor 
loadings superior to 0.30 (Field, 2000). An analysis of internal consistency (Cronbach's alpha) of subscales, considering values greater than 0.70 (Nunnally, 1978), was also performed. Secondly, a confirmatory factor analysis was performed to test the degree of overall adequacy of the general model underlying the PSCS- Car, and the alternative model arising from the EFA, and their respective alternative models. The quality of the factorial models took into account the following indices and benchmarks (Marôco, 2010): X2, X2/df ([2.0-5.0]), CFI (Comparative Fit Index; > 0.90), PCFI (Parsimony Comparative Fit Index), GFI (Goodness-ofFit-Index; > 0.90) PGFI (Parsimony Goodness-ofFit-Index), RMSEA (Root Mean Square Error of Approximation; < 0.08), P[rmsea $\leq 0.05]$. It have been considered statistically significant the results with a significance value less than $0.05(\mathrm{p}<0.05)$.

\section{Results}

Descriptive analyses of the PSCS-Car indicate a distribution of the participants' answers by all of the range of the Likert scale, on all items, with the exception of item 4.3. The comparison of the mean of each item with the theoretical mean point indicates that the obtained answers always lie around this value. However, there is a slight positive deviation, in the items related to the difficulty and poor performance of the social situations, and a slight negative deviation, in the items related to the ease and excellent performance of the social situations. The interpretation of the $z$-scores associated with the skewness and kurtosis coefficients suggest an asymmetric negative and platykurtic distribution in the majority of the items. Regarding the analysis of the discriminative power, results range from 0.460 to 0.575 . Also regarding the internal consistency, the obtained results were greater than 0.89 on all items. Table 1 presents the main descriptive results.

The exploratory factor analysis, performed using the varimax method, with an unspecified number of factors, indicates that the tests of the intercorrelation matrix, such as the test of Keyser-Meyer-Olkin $(\mathrm{KMO}=0.819)$, e o Bartlett's test $\left(X^{2}=8114.107\right.$; $\mathrm{gl}=276 ; \mathrm{p}=0.000)$, have appropriate results. It has been identified eight factors that explain $79.16 \%$ of the total variance of the items. The first six factors correspond to the social situations constituting the scale: (a) Lead a group situation (Factor1: items 3.1 to 3.4); (b) Student visitor situation (Factor 2: items 6.1 to 6.4); (c) Double date situation (Factor 3: items 2.1 to 2.4); (d) Friend counselor situation (Factor 4: items 4.1 to 4.4); (e) Parents' meeting situation (Factor 5: items 5.1 to 5.4); and Homework situation (Factor 6: items 1.1 to 1.4). The remaining two factors include items of poor performance of individuals in any social situation considered (Factor 7: items 1.3 to 6.3 ) and the excellent performance of individuals in any social situation considered (Factor 8: items 1.4 to 6.4). The factor loading of each item, in the respective factor, is greater than 0.30 , being the minimum obtained 0.393 (item 4.4). Regarding the degree of communality, all items exceed 0.50 , being the lowest result of 0.726 (item 1.3). The analysis of internal consistency of this factorial structure indicates results ranging from 0.766 (factor 8) to 0.862 (factor 1).

The confirmatory factor analysis was developed to assess the degree of global fit of the theoretical model underlying the PSCS to the empirical data, by comparison with the model resulting from the AFE, previously presented, and also confirmed in a previous study with students from the $8^{\text {th }}$ grade (Pinto, Taveira, Candeias \& Araújo, 2013). The two models were tested, and their respective alternative models. Table 2 presents the results obtained in the evaluation of the fit indices of each model.

Initially, the General model (model 1), consisting of six factors, corresponding to the six social situations of the scale has been tested. This model shows unsatisfactory fit indices $\left(X^{2} / \mathrm{df}=10.377\right.$, $\mathrm{CFI}=0.703, \mathrm{GFI}=0.638, \mathrm{RMSEA}=0.128, \mathrm{P}[\mathrm{rm}-$ sea $\leq 0.05]<0.000$ ). This situation has prompted the development of an alternative model consisting of the same six factors, with correlations among all (model 1.1). The results achieved are equally unacceptable.

Next, the model of social competence in career, consisting of eight factors, resulting from the EFA, has been tested. This model presents unacceptable fit indices $\left(X^{2} / \mathrm{df}=6.202, \mathrm{CFI}=0.843, \mathrm{GFI}=0.799\right.$, 
TABLE 2.

Descriptive Analysis of the PSCS-Car's Items

\begin{tabular}{|c|c|c|c|c|c|}
\hline Situations/ Items & $\begin{array}{l}\mathrm{M} \pm \mathrm{SD} \\
\text { Skewness }\end{array}$ & \multicolumn{2}{|c|}{ Coefficients } & \multirow[t]{2}{*}{$\begin{array}{c}\text { Corrected item-total } \\
\text { correlations }\end{array}$} & \multirow[t]{2}{*}{$\begin{array}{c}\text { Cronbach's alpha if } \\
\text { item deleted }\end{array}$} \\
\hline Homework situation & & & & & \\
\hline Item 1.1 & $3.67 \pm .929$ & -4.98 & 0.789 & 0.460 & 0.896 \\
\hline Item 1.2 & $3.49 \pm .914$ & -4.1 & -0.446 & 0.481 & 0.895 \\
\hline Item 1.3 & $3.94 \pm .769$ & -4.81 & 0.69 & 0.457 & 0.896 \\
\hline Item 1.4 & $3.41 \pm 0.84$ & -3.81 & 0.466 & 0.512 & 0.894 \\
\hline \multicolumn{6}{|c|}{ Double date situation } \\
\hline Item 2.1 & $3.66 \pm 1.06$ & -4.05 & -2.62 & 0.407 & 0.897 \\
\hline Item 2.2 & $3.45 \pm 1.05$ & -2.43 & -3.31 & 0.418 & 0.897 \\
\hline Item 2.3 & $3.98 \pm .816$ & -4.82 &. .289 & 0.469 & 0.895 \\
\hline Item 2.4 & $3.61 \pm .864$ & -3.83 & 0.161 & 0.486 & 0.895 \\
\hline \multicolumn{6}{|c|}{ Lead a group situation } \\
\hline Item 3.1 & $3.38 \pm 1.03$ & -1.57 & -2.81 & 0.514 & 0.894 \\
\hline Item 3.2 & $3.21 \pm .976$ & -1.35 & -2.41 & 0.506 & 0.895 \\
\hline Item 3.3 & $3.76 \pm .857$ & -5.36 & 1.65 & 0.531 & 0.894 \\
\hline Item 3.4 & $3.31 \pm .913$ & -2.96 & -1.05 & 0.542 & 0.894 \\
\hline \multicolumn{6}{|c|}{ Friend counselor situation } \\
\hline Item 4.1 & $3.76 \pm .0999$ & 3.97 & -2.81 & 0.478 & 0.895 \\
\hline Item 4.2 & $3.59 \pm 0.994$ & 3.01 & -2.77 & 0.431 & 0.896 \\
\hline Item 4.3 & $3.97 \pm 0.817$ & -3.44 & -2.73 & 0.494 & 0.895 \\
\hline Item 4.4 & $3.58 \pm 0.867$ & -3.18 & -0.926 & 0.507 & 0.895 \\
\hline \multicolumn{6}{|c|}{ Parents' meeting situation } \\
\hline Item 5.1 & $3.41 \pm 1.04$ & -2.72 & -2.58 & 0.478 & 0.895 \\
\hline Item 5.2 & $3.15 \pm 1.05$ & -1.07 & -2.78 & 0.509 & 0.894 \\
\hline Item 5.3 & $3.77 \pm .859$ & -3.03 & -1.75 & 0.569 & 0.893 \\
\hline Item 5.4 & $3.27 \pm .924$ & -2.64 & -0.745 & 0.510 & 0.894 \\
\hline \multicolumn{6}{|c|}{ Student visitor situation } \\
\hline Item 6.1 & $3.38 \pm 1.04$ & -2.29 & -2.73 & 0.522 & 0.894 \\
\hline Item 6.2 & $3.18 \pm 0.986$ & -0.225 & -2.73 & 0.490 & 0.895 \\
\hline Item 6.3 & $3.75 \pm 0.878$ & -4.58 & 0.534 & 0.575 & 0.893 \\
\hline Item 6.4 & $3.30 \pm 0.900$ & -2.79 & -0.618 & 0.535 & 0.894 \\
\hline
\end{tabular}

Source: own work

RMSEA $=0.096, P[$ rmsea $\leq 0.05]<0.000$ ). Therefore, two alternative models were developed: 2.1 Model of social competence in career with correlation between the excellent performance and the poor performance factors; and, 2.2 Model of social competence in career with correlation between all factors ( 6 social situations and 2 performance). The latter model provides excellent fit indices $\left(X^{2} / \mathrm{df}=\right.$ 4.229, $\mathrm{CFI}=0.909, \mathrm{GFI}=0.738, \mathrm{RMSEA}=0.075$, $\mathrm{P}[\mathrm{rmsea} \leq 0.05]<0.000)$, indicating that, unlike all other models previously discussed, this solution fits adequately to the empirical data collected.

Figure 1 shows the selected model, as well as, the correlation coefficients and the factor structure of PSCS-Car. All items have high standardized weight factors, particularly those items that saturate in the six factors relating to social situations. In the case of the performance factors, the factorial weights are only good or reasonable. There are also significant and causal relations, but reduced, among all the factors. 
TABLE 3.

Factor Loadings for Exploratory Factor Analysis with Varimax Rotation of the PSCS- Car

\begin{tabular}{|c|c|c|c|c|c|c|c|c|c|}
\hline \multirow{2}{*}{ Items } & \multicolumn{8}{|c|}{ Components } & \multirow{2}{*}{ h2 } \\
\hline & 1 & 2 & 3 & 4 & 5 & 6 & 7 & 8 & \\
\hline Item $1.1^{*}$ & & & & & & 0.805 & & & 0.756 \\
\hline Item 1.2 & & & & & & 0.834 & & & 0.785 \\
\hline Item $1.3 *$ & & & & & & 0.600 & 0.581 & & 0.726 \\
\hline Item 1.4 & & & & & & 0.671 & & 0.468 & 0.747 \\
\hline Item $2.1 *$ & & & 0.853 & & & & & & 0.814 \\
\hline Item 2.2 & & & 0.887 & & & & & & 0.851 \\
\hline Item $2.3^{*}$ & & & 0.687 & & & & 0.484 & & 0.741 \\
\hline Item 2.4 & & & 0.706 & & & & & 0.435 & 0.751 \\
\hline Item $3.1^{*}$ & 0.846 & & & & & & & & 0.836 \\
\hline Item 3.2 & 0.853 & & & & & & & & 0.822 \\
\hline Item $3.3^{*}$ & 0.702 & & & & & & 0.493 & & 0.778 \\
\hline Item 3.4 & 0.742 & & & & & & & 0.456 & 0.822 \\
\hline Item $4.1 *$ & & & & 0.839 & & & & & 0.820 \\
\hline Item 4.2 & & & & 0.880 & & & & & 0.831 \\
\hline Item $4.3^{*}$ & & & & 0.630 & & & 0.579 & & 0.772 \\
\hline Item 4.4 & & & & 0.737 & & & & 0.393 & 0.764 \\
\hline Item $5.1^{*}$ & & & & & 0.857 & & & & 0.833 \\
\hline Item 5.2 & & & & & 0.855 & & & & 0.837 \\
\hline Item $5.3 *$ & & & & & 0.624 & & 0.524 & & 0.740 \\
\hline Item 5.4 & & & & & 0.683 & & & 0.509 & 0.789 \\
\hline Item $6.1^{*}$ & & 0.826 & & & & & & & 0.807 \\
\hline Item 6.2 & & 0.868 & & & & & & & 0.831 \\
\hline Item $6.3 *$ & & 0.629 & & & & & 0.537 & & 0.758 \\
\hline Item 6.4 & & 0.747 & & & & & & 0.404 & 0.787 \\
\hline Eigenvalues & 7.347 & 2.549 & 1.820 & 1.729 & 1.622 & 1.468 & 1.333 & 1.132 & \\
\hline$\%$ of variance explained & 30.61 & 10.62 & 7.58 & 7.20 & 6.76 & 6.12 & 5.55 & 4.72 & \\
\hline Cronbach's alpha & 0.862 & 0.853 & 0.841 & 0.846 & 0.842 & 0.803 & 0.788 & 0.766 & \\
\hline
\end{tabular}

Note. Factor loadings $>0.30$ are in boldface.

*Reverse scored items

Source: own work

\section{Discussion and conclusion}

This study aimed to perform the analysis of the psychometric characteristics of an instrument designed to assess social competence within career development situations - The Perceived Social Competence in Career Scale (PSCS-Car; Araújo, Taveira, \& Candeias, 2009). To this end, it was used a sample of 571 students, who were attending the 10th and 11th school grades of the Portuguese educational system. Exploratory factor analysis were carried out for a first identification of the structure underlying the scale, as well as, a confirmatory factor analysis for the purpose of testing the degree of adjustment of the empirical data to the factorial model resulting from the exploratory factor analysis, as compared with the theoretical model originally developed, and their respective alternative models.

The descriptive results indicate that there are difficulties regarding the normality of the collected empirical data. Specifically, there is a tendency for participants to respond to the PSCS-Car using the 
TABLE 4.

Fit Indices of Models of Social Competence

\begin{tabular}{|c|c|c|c|c|c|c|c|c|c|}
\hline Model & $x^{2}$ & $\mathrm{df}$ & $X^{2} / \mathrm{df}$ & $\mathrm{CFI}$ & PCFI & GFI & PGFI & RMSEA & $\mathrm{P}(\mathrm{msea} \leq .05, \mathrm{p}=)$ \\
\hline 1 - General model (6 factors) & $2614.919 * * *$ & 252 & 10.377 & 0.703 & 0.642 & 0.638 & 0.536 & 0.128 & 0.000 \\
\hline $\begin{array}{l}1.1 \text { - General model with } \\
\text { correlation between all factors ( } 6 \\
\text { factors) }\end{array}$ & $204.967 * * *$ & 237 & 8.629 & 0.773 & 0.664 & 0.698 & 0.551 & 0.116 & 0.000 \\
\hline $\begin{array}{l}2 \text { - Model of social competence } \\
\text { in career ( } 8 \text { factors) }\end{array}$ & $1488.386^{* * * *}$ & 240 & 6.202 & 0.843 & 0.733 & 0.799 & 0.639 & 0.096 & 0.000 \\
\hline $\begin{array}{l}2.1 \text { - Model of social } \\
\text { competence in career with } \\
\text { correlation between the } \\
\text { excellent performance and poor } \\
\text { performance factors }\end{array}$ & $1427.609 * * *$ & 239 & 5.973 & 0.851 & 0.737 & 0.798 & 0.636 & 0.093 & 0.000 \\
\hline $\begin{array}{l}2.2 \text { Model of social competence } \\
\text { in career with correlation } \\
\text { between all factors } \\
\text { ( } 6 \text { situations }+2 \text { performances) }\end{array}$ & $947.324 * * *$ & 224 & 4.229 & 0.909 & 0.738 & 0.869 & 0.649 & 0.075 & 0.000 \\
\hline
\end{tabular}

Note. CFI = Comparative Fit Index; PCFI = Parsimony Comparative Fit Index; GFI = Goodness-of-Fit-Index; PGFI = Parsimony Goodness-of-Fit-Index; RMSEA = Root Mean Square Error of Approximation.

$* * * \mathrm{p}<0.001$

Source: own work

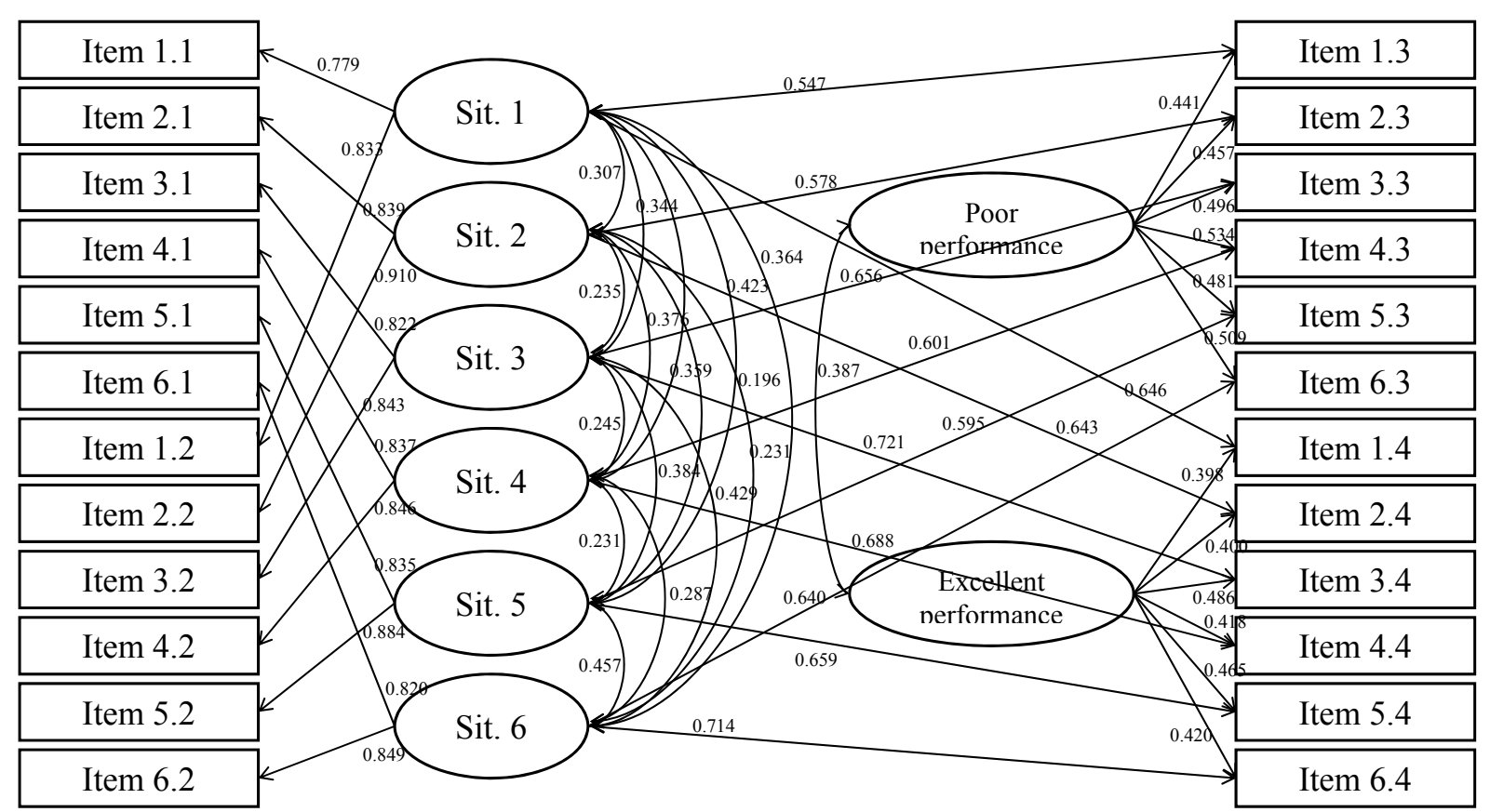

Figure 1: Empirical Results from Confirmatory Factor Analysis of the Model of Social Competence in Career

Figure 1: Empirical Results from Confirmatory Factor Analysis of the Model of Social Competence in Career Source: own work 
upper and intermediate points of the Likert scale, both in the ease and difficulty items, and both in poor performance and excellent performance items. A comparison between the average results obtained in the ease and difficulty of items, and in the poor and excellent performance items, in all situations, indicates that the mean scores are always higher in the difficulty and poor performance items. This refers to a relatively low perception of these students on their ability to handle the presented social situations within career, what may be due to the formulation and presentation of the items, as well as, to some face validity issues. On the one hand, the difficulty and poor performance items are presented prior to the presentation of the ease and excellent performance items, which may be responsible for the students' tendency to respond to the latter in line with their initial responses. On the other hand, some students considered problematic to differentiate between what is being asked in the different items, and the ease and excellent performance items are often perceived as a way of checking the accuracy of their responses to the difficulty and poor performance items, respectively.

Regarding the exploratory factor analysis results, it was confirmed the existence of a factor structure underlying the scale consisting of eight factors. Of these, six factors correspond to the presented interpersonal situations within career, encompassing items that, in theory, were already anticipated that could be associated to each of these social situations (Candeias $\&$ Almeida, 2005). The remaining two factors are related to the items assessing poor performance and excellent performance, transversely to the different social situations. Importantly, these results do not corroborate the theoretical model of six factors proposed by Candeias (2001) for the original instrument, from which PSCS- Car was developed. The model thus accounts for about $80 \%$ of the total variance of the items, compared with the original model that accounts for about $65 \%$. It is also noteworthy that the factor loadings of the items for each factor are higher in this model compared to the original model of six factors (Candeias, 2008; Candeias \& Almeida, 2005). However, it is emphasized that the two factors related to poor performance and excellent performance have items with factor loadings slightly lower than the fac- tor loadings of the items of the remaining six factors, although greater than 0.30, and their Cronbach's alphas are also lower, although considered adequate.

In what concerns the confirmatory factor analysis, it was analyzed the degree of adjustment of empirical data to the original model of six factors, as well as, the model of eight factors resulting from the exploratory factor analysis, and their respective alternative models. The 2.2 model, of eight interrelated factors, showed the more robust fit indices to the empirical data. In this factor solution, the six situational factors are interrelated with each other, but not with the two performance factors. In turn, the two performance factors are only related to one another. This seems to demonstrate the existence of a perception of ease/difficulty and poor/excellent performance which is situational, that is, is specific of the social situation within career development that is being presented. But it also indicates the existence of a global perception of performance in social situations within career, regardless of the specific situation presented. In other words, students tend to develop beliefs and prior expectations of performance, in different social situations through the basics of learning, including observation and experience (Schunk, 2000). These self-efficacy beliefs will foster or inhibit their involvement in these situations, depending on whether students feel they have, or not have, all the skills, knowledge and behaviors that are necessary to deal effectively with a particular task/situation. Their involvement can help to strengthen a self-perception as having a poor or excellent performance to deal with these situations. Consequently, situations in which their performance is excellent are often perceived as easy, and situations where their performance is poor are often perceived as difficult. In general, it can be stated that these results lead us to the idea that this social competence scale is essentially a self-assessment scale about the level of performance of youth in diverse career interpersonal situations. In this particular case, this group of secondary school students seems to present an overall view of themselves as having a low competence to cope with social situations in general, and its performance is slightly better or worse according to the specific situation they face. 
In conclusion, the obtained results are congruent with those previously obtained in similar studies with students from $8^{\text {th }}$ grade (Pinto, Taveira, Candeias, \& Araújo, 2013). It is suggested therefore that in the future to be continued this line of research by studying the invariance of the factor structure now proposed with different groups regarding sex, age, and years of schooling. Some authors have pointed out that this comparative study of the structural factor between different groups is a relevant step in what concerns the validation of psychological instruments (e.g., Fernandes, \& Vasconcelos-Raposo, 2010). have pointed out that this comparative study of the structural factor between different groups is a relevant step in what concerns the validation of psychological instruments.

\section{References}

Candeias, A. A. (2001). Prova de Avaliação de Competência Social [Perceived Social Competence Scale]. Évora: University of Évora.

Candeias, A. A., \& Almeida, L. S. (2005). A sua avaliação em contextos de desenvolvimento e educação [Social competence: it assessment in development and educational contexts]. Revista de Psicologia, Educação e Cultura, 2(9), 359-378.

Candeias, A. A. (2008). Prova de Avaliação de Competência Social [Perceived Social Competence Scale]. Évora: University of Évora.

Araújo, A., Taveira, M. C., \& Candeias, A. A. (2009). Prova de Avaliação de Competência Social em Contexto de Carreira [Perceived Social Competence in Career Scale]. Braga: University of Minho.

Pinto, J. C. (2010). Gestão Pessoal da Carreira: estudo de um modelo de intervenção psicológica com bolseiros de investigação [Career self-management: study of na intervention model with $\mathrm{PhD}$ students]. (Unpublished doctoral thesis). Braga: School of Psychology, University of Minho.

Carvalho, V. (2001). Inteligência Social em Alunos do $8^{\mathrm{o}}$ ano: Implicações para o Questionamento Ético dos Projectos de Vida [Social intelligence in 8th grade students]. (Unpublished master thesis). Braga: School of Psychology, University of Minho.

Pinto, J. C., Taveira, M. C., Candeias, A., \& Araújo, A. (2013). Análise Fatorial Confirmatória da Prova de
Avaliação de Competência Social face à Carreira. Psicologia: Reflexão e Crítica, 26(3), 469-478..

Cecconello, A. M. (1999). Competência social, empatia e representação mental da relação de apego em famílias em situação de risco [Social competence, empathy and mental reprsentation of attachment of families at risk ]. Unpublished master thesis. Porto Alegre: Federal University of Rio Grande do Sul.

Fernandes, H. M., \& Vasconcelos-Raposo, J. J. B. (2010). Análise fatorial confirmatório do TEOSQp. Psicologia, Reflexão e Crítica, 23(1), 92-101.

Field, A. (2000). Discovering statistics using SPSS for Windows. Thousand Oaks: Sage Publications Inc.

Greenhaus, J. H., Callanan, G. A., \& Godshalk, V. M. (2010). Career management (4⿳亠丷厂 $\mathrm{ed}$ e). Thousand Oaks, CA: Sage Publications.

Humphrey, N., Kalambouka, A, Wigelsworth, M., Lendrum, A., Deighton, J., \& Wolpert, M. (2011). Measures of social and emotional skills for children and young people: a systematic review. Educational and Psychological Measurement, 71, 617-637.

Lemos, M. S., \& Meneses, H. I. (2002). A avaliação da competência social: versão portuguesa da forma para professores do SSRS [Assessment of social competence: portuguese version of the SSRS for teachers]. Psicologia: Teoria e Pesquisa, 18(3), 267274.

Marôco, J. (2010). Análise de Equações Estruturais [Structural Equation Modelling]. Lisboa: Report Number.

Nunnally, J. C. (1978). Psychometric theory. New York: McGraw-Hill Inc.

Pinto, J. C., Taveira, M. C., Candeias, A., \& Araújo, A. (2013). Análise Fatorial Confirmatória da Prova de Avaliação de Competência Social face à Carreira. Psicologia: Reflexão e Crítica, 26(3), 469-478.

Railiene, A., \& Gudzinskiene, V. (2012). Development of social skills and career competences in child daycare centres: attitudes of day-care centre specialist. Social work, 11, 85-96.

Shunk, D. H. (2000). Learning: introduction, issues, and historial perspectives. InSchunk, D. H. Learning theories: an educational perspective (pp.1-29). Upper Saddle River, NJ: Pearson Education.

Waters, E., \& Sroufe, L. A. (1983). Social competence as a developmental construct. Developmental review, 3, 79-97. 